REPORTS OF MORPHOLOGY
$\begin{gathered}\text { Official Journal of the Scientific Society of Anatomists, } \\ \text { Histologists, Embryologists and Topographic Anatomists } \\ \text { of Ukraine } \\ \text { journal homepage: https://morphology-journal.com }\end{gathered}$

\title{
Ultrastructural condition of rats periodontal tissue in opioid influence during two weeks and after its four-week withdrawal on correction
}

\author{
Fik V.B. ${ }^{1}$, Paltov Ye.V. ${ }^{1}$, Kryvko Yu. Ya. ${ }^{2}$ \\ ${ }^{1}$ Danylo Halytsky Lviv National Medical University, Lviv, Ukraine \\ ${ }^{2}$ Andrey Krupinsky Lviv Medical Academy, Lviv, Ukraine
}

\section{ARTICLE INFO}

Received: 22 February, 2019

Accepted: 20 March, 2019

UDC: $611.311-$

018.73:615.214.24:615.03:616-076.4

\section{CORRESPONDING AUTHOR}

e-mail: fikvolodymyr@ukr.net Fik V.B.

\begin{abstract}
Given that the dental status of drug addicts is burdened with numerous diseases of the tissues and organs of the oral cavity, the issues of developing an optimal scheme of therapeutic tactics for the purpose of restoring their trophic and balance of the oral microflora against opioid background remain relevant in modern periodontology. The aim of the study was to investigate the ultrastructure of periodontal tissues with experimental two-week opioid action and after its abolition for four weeks under conditions of complex medical corrective action. The study material was white male rats (22) of reproductive age (4.5-6 months), Wistar line, with an average body weight of $200 \mathrm{~g}$. The animals were injected with nalbuphine for two weeks, the dose was $0.212 \mathrm{mg} / \mathrm{kg}$ and its subsequent withdrawal for four weeks. In order to correct pathological changes arising from the action of opioids in periodontal tissues, pentoxifylline and the antibiotic ceftriaxone were used. Pentoxifylline was administered intramuscularly daily for four weeks after opioid withdrawal (3-6 weeks) at a dose of $2.857 \mathrm{mg} / \mathrm{kg}$. Ceftriaxone was administered once for 11 days at the end of the experiment (5-6 weeks) at a dose equivalent to rat (2.857 $\mathrm{mg} / \mathrm{kg}$ ). Periodontal tissue sampling was performed in the area of the papilla, followed by ultrastructural examination. Submicroscopically found that the structural components of the periodontium have minor changes, their organization is close to normal. The ultrastructure of all sections of the epithelial lining of the mucosa is characterized by a layered arrangement of cells. In epitheliocytes, part of the nuclei has invaginations of the nuclear membrane, indicating their functional activity, clear outlines of compact nucleolus and plasmalemma. In the cytoplasm, most organelles are virtually unchanged, in the mitochondria there are cristae, clearly identified tonofilaments, desmosomal contacts and the basement membrane. Plasmalemma contours are clear, the intercellular contacts are preserved, and the individual intercellular regions appear thickened. The periodontium is represented by well-ordered collagen fiber bundles, the cellular components are unchanged. The detected submicroscopic structure of fibroblasts indicates their synthetic activity aimed at updating the intercellular substance of connective tissue. Electron microscopic studies of the hemocapillaries of the mucous membrane of the gums of animals of this group showed that in their wide lumens there are formed blood elements, mainly erythrocytes. The nuclei of the endothelial cells have an ellipsoidal shape, small invasions of nuclear membrane, clear nuclear membranes, organelles are few. Perivascular spaces without signs of edema. Venules are unaltered, have wide lumens, cytoplasmic portions of endothelial cells are not wide, their nuclear parts protrude into the lumen, the basement membrane is thickened in places. Thus, sub-microscopically established that when canceling opioid analgesic and drug correction at the end of the two-week action of opioid there are signs of positive dynamics in the structural components of periodontium, which is explained by the pathogenic reasonableness of pentoxifylline when disturbed by the opioid analgesia and by medication of the opioid analgesia and medication. effect on the ultrastructural and functional organization of periodontal tissues. Keywords: electron microscopic studies, periodontal tissues, rats, opioid analgesic, correction.
\end{abstract}




\section{Introduction}

Uncontrolled or deliberate misuse of opioid medications in chronic pain is a determining risk of patient addiction, leading to the development of withdrawal syndrome and high overdose death rates [3, 10]. Diseases of the organs and tissues of the oral cavity are most commonly found in drug addicts, whose dental status is burdened with numerous diseases of the tissues of the tooth and mucous membrane of the oral cavity [18, 19, 23]. According to the professional scientific literature, the main features of the pathology of the oral cavity in drug addicts include the slow course of the disease, the inhibition of the blockade of acute phenomena and the progression of bone damage [22].

In the pathogenesis of periodontitis, which also takes place under the influence of narcotic substances, the leading role belongs to disorders of the microcirculation, lack of antioxidant protection and dysbiotic changes of the microbiota in the oral cavity $[4,5,13,14,17,18,20,21,23]$. The course of periodontitis in the chronic process develops against the background of inhibition of phagocytic protection, where the immune response does not depend on the severity of pathomorphological changes, and the function of macrophages when interacting with bacterial flora can cause excessive production of toxic substances that damage the periodontal tissues [18]. Therefore, there is a need to develop the optimal treatment tactics for opioid agents, with the aim of restoring tissues and organs, improving their trophism and restoring the balance of microflora [7, 11, 12, 18]. Since we cannot study periodontal tissues in patients in dynamics at different timing of opioid exposure, the experimental study allows us to simulate the pathological process in periodontal animals and to apply a complex medication correction of the destructive changes that occur during opioid exposure.

The aim of the study was to investigate periodontal tissue biopsy specimens under the experimental action of opioid for two weeks and after its four-week withdrawal under conditions of complex medical corrective action at the ultrastructural level.

\section{Materials and methods}

White rats of reproductive age of the Wistar line $(n=22)$, with an average weight of $200 \mathrm{~g}, 4.5-6$ months old, were used as the study material. The experimental animals were divided into 2 groups. The first group consisted of intact animals $(n=10)$, the second group was rats injected with nalbuphine, the opiate receptor antagonist agonist group for the first two weeks at $0.212 \mathrm{mg} / \mathrm{kg}$, and the subsequent withdrawal of the opioid drug over the four weeks. In order to correct pathological changes arising from the action of opioids in periodontal tissues, pentoxifylline and the antibiotic ceftriaxone were used. Pentoxifylline was administered intramuscularly daily for four weeks after opioid withdrawal (3-6 weeks) at a dose of $2.857 \mathrm{mg} / \mathrm{kg}$. Ceftriaxone was administered once for 11 days at the end of the experiment (5-6 weeks) in a dose equivalent to rat $-2.857 \mathrm{mg} / \mathrm{kg}$. As a control, 3 male rats were injected with $0.9 \%$ sodium chloride solution. Animals were kept under standard vivarium conditions and experiments were carried out in accordance with ethical principles in accordance with the provisions of the "European Convention for the Protection of Vertebrate Animals Used for Experimental and Other Scientific Purposes". For electron microscopic examination, fragments of periodontal soft tissue were used in the area of the gum margin. The tissue pieces were fixed in a $2.5 \%$ solution of glutaraldehyde and in a $1 \%$ solution of osmium tetroxide on phosphate buffer $\mathrm{pH}$ 7.2-7.4, dehydrated in alcohols and propylene oxide and poured into a mixture of epoxy resins with araldite [9]. UMPT3m ultramicrotome produced ultrathin sections that were counterstained with uranyl acetate and lead citrate and studied in an electron microscope PEM100-01.

\section{Results}

Conducted electron microscopic studies have shown that in the rats of this subgroup structural components of the periodontium have minor changes, their organization is close to normal. The ultrastructure of all sections of the epithelial lining of the mucosa is characterized by a layered arrangement of cells. In the basal layer, the epithelial cells of the free part of the rat gums have an oval or rounded nucleus with clear outline of the nuclear membrane, a small perinuclear space. The cytoplasm includes numerous tonofilaments, small mitochondria, many ribosomes and a polysome. The basal membrane to which cells of the basal layer are attached by means of a hemidesmosome is clearly defined (Fig. 1).

The epitheliocytes of the spinous layer are smaller in

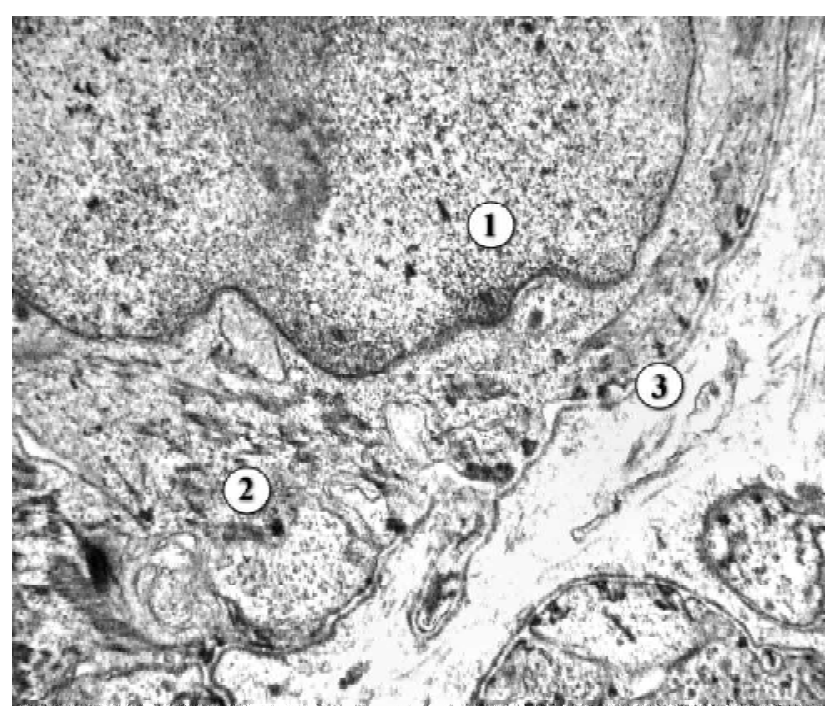

Fig. 1. Ultrastructure of the epitheliocyte of basal layer of the free epithelium of the rat gingiva after six weeks: two weeks of opioid administration, four weeks after its abolition and correction with pentoxifylline and ceftriaxone. 1 - rounded nucleus, 2 - cytoplasm of epitheliocytes, 3 - basement membrane. x14000. 


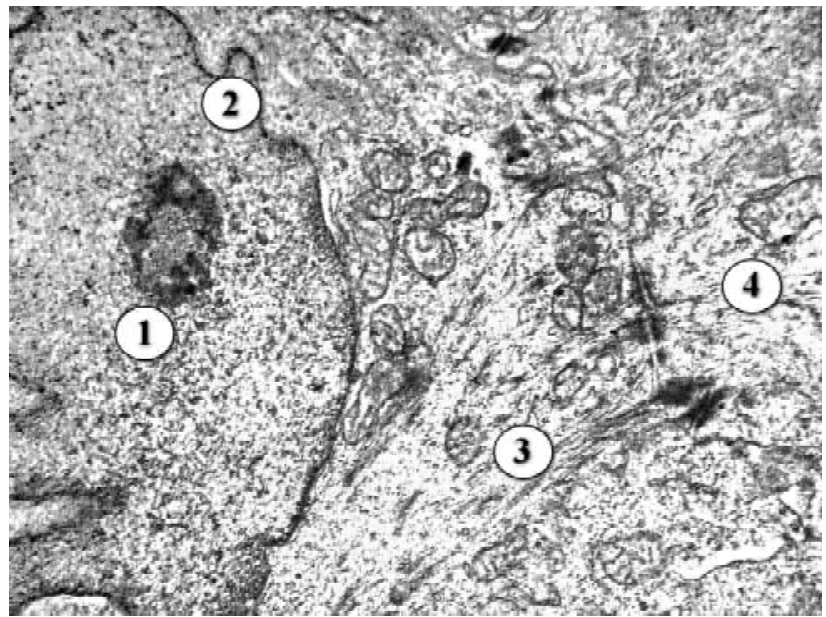

Fig. 2. Ultrastructure of the epitheliocyte spinous layer of the rat gingival epithelium after six weeks: two weeks of opioid administration, four weeks after its abolition, and correction with pentoxifylline and ceftriaxone. 1 - nucleolus, 2 - intussusception of nuclear membrane, 3 - mitochondria, tonofilaments, 4 - intercellular contacts. x14000

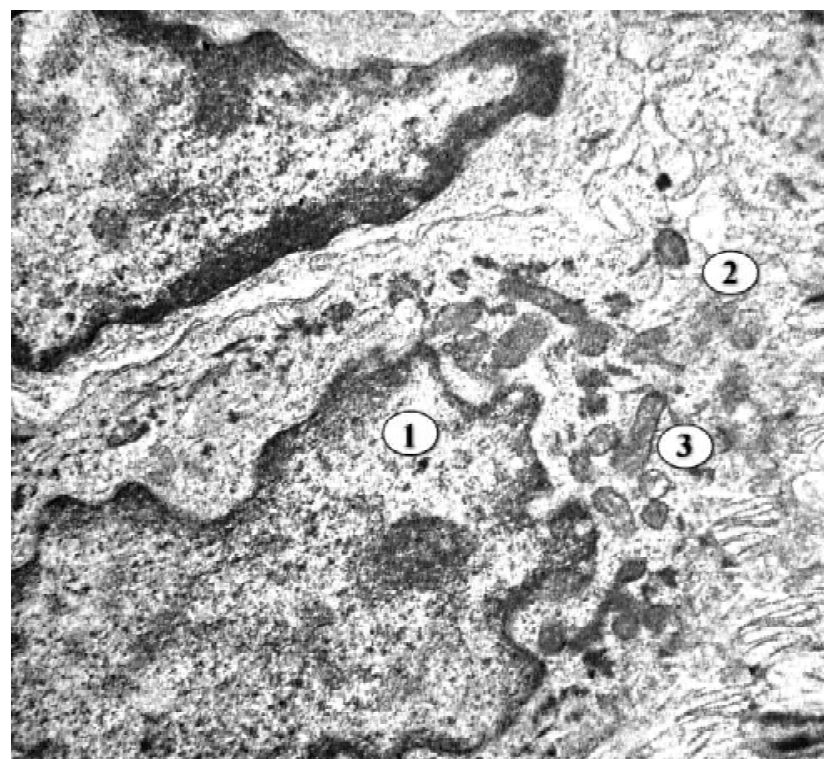

Fig. 3. Ultrastructure of the epitheliocyte spinous layer of the epithelium of the attached part of the rat gingiva after six weeks: two weeks of opioid administration, four weeks of its abolition, and correction with pentoxifylline and ceftriaxone. 1 - nucleus, 2 cytoplasm of epitheliocyte, 3 - mitochondria. x12000.

size, separated from each other by narrow intercellular spaces, but tightly interconnected by desmosomal contacts. In their cytoplasm many thin tonofibrils. The density of organelles is low, there are separate tubules of granular endoplasmic reticulum, small mitochondria, primary lysosomes. Ultrastructural studies of the epithelial plate of the furrow of animals in this group showed that the cells in its layers are also unchanged. No cytoplasm swelling of the epitheliocytes of the basal and spinous layers is noted. However, part of the nuclei of the cells have invasions of nuclear membrane, which indicates their functional activity. Clear outlines of compact nucleolus and plasmalemma are observed. In the cytoplasm, most organelles are virtually unchanged, with clear tonofilaments and desmosomal contacts (Fig. 2). In the granular layer, the epitheliocytes have small elongated, osmiophilic, with irregular contours of the nuclear membrane nucleus. Characteristic of the cytoplasm is the presence of electron-density keratohyalin granules. The stratum corneum is formed by rugose scales formed by degeneratively altered epitheliocytes. This layer is thick in the free part of the mucous membrane of the gums, thin in the area of the epithelium of the gums, and absent in the attached part of the gums.

At the ultrastructural level, it has been found that the epithelium of the attached part of the gums of animals has moderate changes and they reflect its functional activity. This applies to the nuclei of cells, which are predominantly elongated with shallow invasions of the nuclear membrane, and euchromatin is noted in the karyoplasm. In the cytoplasm, mitochondrial hyperplasia is observed, they are small, elongated or rounded, and cristae are present in their moderately osmiophilic matrix. Plasmalemma contours are clear, intercellular contacts are preserved, and individual intercellular areas appear thickened (Fig. 3).

Submicroscopic studies of the periodontal organization showed that it is represented by well-ordered collagen fibers, between which are layers of loose connective tissue. Cellular components of the periodontium - fibroblasts, fibrocytes, tissue basophils, lymphocytes, plasmocytes, macrophages are also unchanged. In fibroblasts the nuclei have a long or rounded shape, a developed cytoplasm and a small process. In their cytoplasm there are organelles of general purpose, granular endoplasmic reticulum, Golgi complex, mitochondria, ribosomes, as well as primary polyribosomes, rarely secondary lysosomes (Fig. 4).

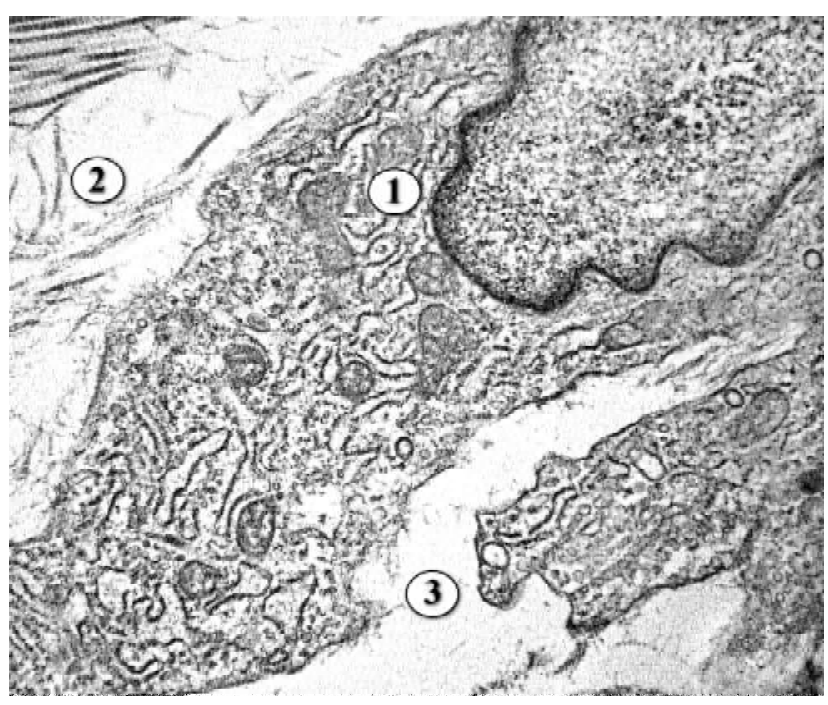

Fig. 4. The ultrastructure of the rat periodontium after six weeks: two weeks of opioid administration, four weeks after withdrawal, and correction with pentoxifylline and ceftriaxone. 1 - nucleus and cytoplasm of fibroblast, 2 - collagen fibrils, 3 - amorphous component of intercellular substance. $\times 17000$. 


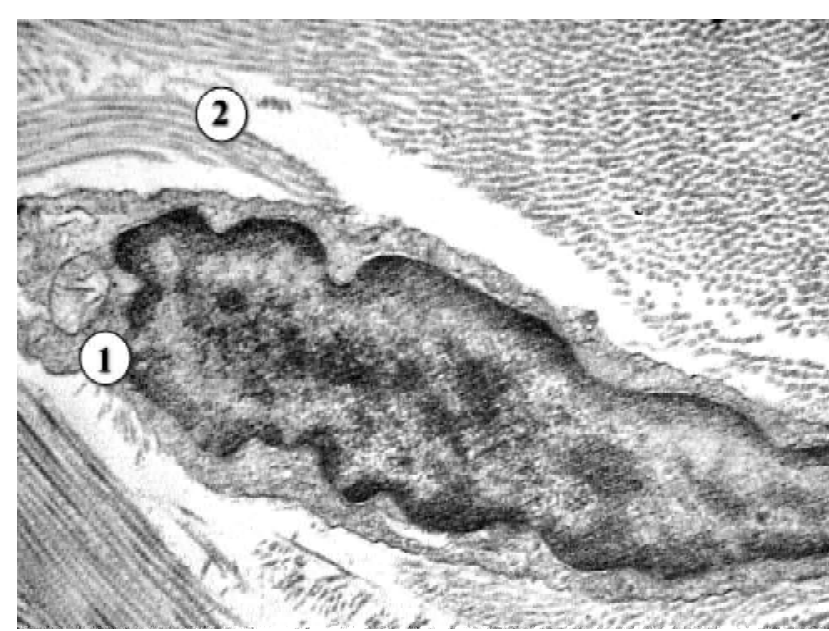

Fig. 5. The ultrastructure of the rat periodontium after six weeks: two weeks of opioid administration, four weeks after withdrawal, and correction with pentoxifylline and ceftriaxone. 1 - nucleus and cytoplasm of fibrocytes, 2 - collagen fiber. $x 17000$.

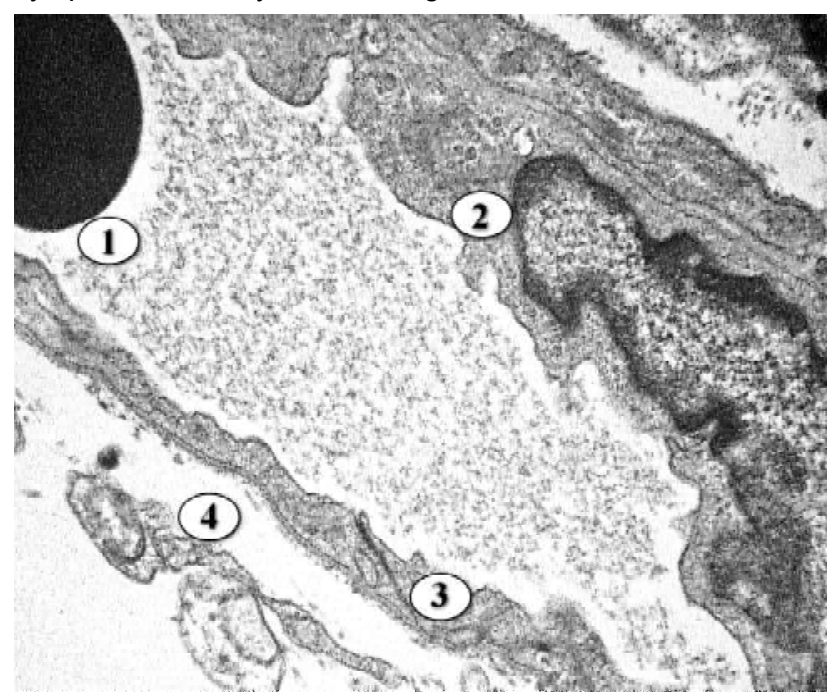

Fig. 6. The hemocapillary ultrastructure of the rat after six weeks: two weeks of opioid administration, four weeks after its abolition, and correction with pentoxifylline and ceftriaxone. 1 - a small lumen with erythrocyte, 2 - the nucleus and cytoplasm of endothelial cell, 3 - the basement membrane, 4 - perivascular space. $x 12000$.

The detected submicroscopic structure of fibroblasts indicates their synthetic activity aimed at updating the intercellular substance of connective tissue. Between the tufts of collagen fibrils, fibrocytes with a much smaller volume of cytoplasm, few organelles, and an elongated nucleus are also found (Fig. 5).

Electron microscopic examination of the hemocapillaries of the mucous membrane of the gums of the animals of this group showed that in their wide lumens there are formed elements of blood, mainly erythrocytes. The wall of the blood capillary is formed by endothelial cells and the basement membrane. The nuclei of the endothelial cells have an ellipsoidal shape, small invasions of the nuclear membrane, and clear nuclear membranes.

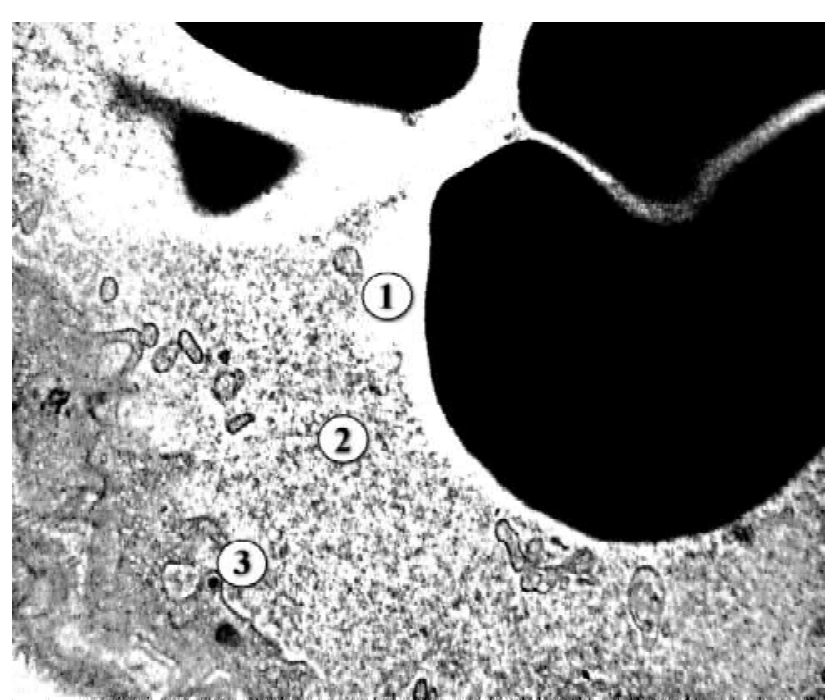

Fig. 7. The ultrastructure of the venous rat after six weeks: two weeks of opioid administration, four weeks after its abolition, and correction with pentoxifylline and ceftriaxone. 1 - a wide lumen with the formed elements of blood, 2 - cytoplasm of endothelial cell, 3 - basal membrane. $\times 15000$.

The organelles are few and they are located mainly in the paranuclear regions of the cytoplasm. The cytoplasmic areas are not wide, with foamy vesicles and caveolae. The luminal part of the endothelial cell plasmalemma forms cytoplasmic patches and microvilli. The basal membrane is narrow, in the form of a relatively uniform ribbon separating the endothelium from the loose connective tissue of its own lamina. Perivascular spaces without signs of edema (Fig. 6).

Submicroscopically during this term, the venules are unchanged. They have a wide lumen, available red blood cells, platelets, rarely neutrophils, lymphocytes. The cytoplasmic regions of the endothelial cells are not wide, their nuclear parts protruding into the lumen. There are few organelles in the cytoplasm, separate non-elastic tubules of the endoplasmic reticulum, small mitochondria, different sizes of vacuoles and vesicles. The basal membrane is thickened in some places, the perivascular spaces are small (Fig. 7).

\section{Discussion}

Given that narcotic substances cause intoxication of many systems and organs, pronounced pathomorphological changes are also observed in periodontal tissues, with further progression of inflammatory process and development of generalized periodontitis [18, 23]. The morpho-functional condition of the periodontium, in particular, the mucous membrane of the gums, as a universal nonspecific criterion for periodontitis, determines the tactics of therapeutic measures that are required for disorders of peripheral microcirculation that cause the development of tissue hypoxia and their energy deficiency $[1,15]$. According to the medical literature, the drug pentoxifylline has a 
pathogenetic validity not only in dysfunction of peripheral circulation, but also it is characterized by anti-inflammatory and antioxidant effects, which was confirmed during experimental and clinical studies [2, 8, 16]. In the pathogenesis of diseases of the mucous membrane of the gums under the action of narcotic drugs is also important dysbiosis and pathogenic microflora of the oral cavity on the background of caries and its complications, which necessitates the need for antibacterial therapy with determination of sensitivity to antibiotics $[6,11,12,18]$.

Thus, despite the long-term withdrawal of opioid after two weeks of its action in animals, we considered it necessary to apply in the experiment a complex corrective action to accelerate reparative processes and normalize the ultrastructural organization of periodontal tissues. At the ultrastructural level, the organization of the gum components is close to the structure of intact animals. Reactive changes in the nuclei and organelles of the cytoplasm of cells of the epithelium of the mucous membrane of the gums are noted. The submicroscopic organization of the periodontal animals of this group is also not significantly different from the norm. The ultrastructure of fibroblasts and macrophages indicates their active state. The positive effect of the complex application of drugs causes a significant normalization of the ultrastructure of the links of the hemomicrocirculatory bed. Moderately blood-filled hemocapillaries and venules are

\section{References}

[1] Babai, O. M. (2016). Condition of periodontal tissues and evaluation of clinical efficacy of essential phospholipids: results of long-term monitoring of patients with generalized periodontitis. Bulletin of problems of biology and medicine, 2(1), 159-163.

[2] Brie, D., Sahebkar, A., Penson, P.E., Dinca, M., Ursoniu, S., Serban, M.C., ... Banach, M. (2016). Effects of pentoxifylline on inflammatory markers and blood pressure: a systematic review and meta-analysis of randomized controlled trials. $J$. Hypertens., 34(12), 2318-2329. doi: 10.1097 / HJH.0000000000001086

[3] Chou, R., Turner, J. A., Devine, E. B., Hansen, R. N., Sullivan, S. D. ... Deyo, R. A. (2015). The effectiveness and risks of longterm opioid therapy for chronic pain: a systematic review for a National Institutes of Health Pathways to Prevention Workshop. Ann. Intern. Med., 162, 276-286. doi: 10.7326/ M14-2559

[4] Cvintarna, I. E., \& Misula, I. R. (2014). The state of lipid peroxidation in periodontal animals in experimental periodontitis with altered body reactivity. Bulletin of scientific research, (4), 127-129. https://doi.org/10.11603/2415-8798.2014.4.4654

[5] Demkovich, A. E. (2015). Violation of immunological reactivity of the organism in the pathogenesis of inflammatory periodontal diseases. Clinical Dentistry, 2, 30-37.

[6] Fik, V. B. (2015). Influence of opioid analgesic on the content and antibiotic sensitivity of the oral microflora of rats. Bulletin of Dentistry, 1(90), 27-32.

[7] Fik, V. B., Paltov, E. V., \& Kryvko, Y. Y. (2018). Morphofunctional peculiarities of the periodontal tissue under conditions of simulated eight-week opioid effect. Deutscher Wissenschaftscherold German Science Herald, 1, 14-17. doi: $10.19221 / 201814$ observed. The endothelial cells, the basement membrane and the perivascular space have a specific structure. The analysis of the peculiarities of the submicroscopic organization of the structural components of the periodontium in the short-term effect of the opioid and its abolition under the correction of pentoxifylline and ceftriaxone was not possible due to the lack of such data in the domestic and foreign professional literature.

Prospects for further research are to study the ultrastructural organization of periodontal tissues under the action of opioids at a later date and the features of drug correction under such conditions.

\section{Conclusions}

1. Submicroscopically found that with the abolition of opioid analgesic and complex corrective effects of drugs after two weeks of opioid exposure, there is a positive dynamic of ultrastructural reorganization in the components of rats' periodontal constituent components.

2. The use of pentoxifylline is explained by its pathogenetic validity in disorders of microcirculation and anti-inflammatory and antioxidant effect, which in combination with the antibacterial agent ceftriaxone provide therapeutic effect on the ultrastructural and functional organization of periodontal cells under the action of opioids.

[8] Genovés, P., Garcia, D., Cejalvo, D., Martin, A., Zaragoza, C., Toledo, A. H., ... Lloris-Carsi, J. M. (2014). Pentoxifylline in liver ischemia and reperfusion. J. Invest. Surg., 27, 114-124. doi: 10.3109/08941939.2013.835454

[9] Glauert, A. M. (1975). Fixation, Dehydration and Embedding of Biological Specimens. In: Practical methods in electron microscopi. North-Hollond: American Elsevier.

[10] Guy, G. P. Jr., Zhang, K., Bohm, M. K., Losby, J., Lewis, B., Young, R., ... Dowell, D. (2017). Vital signs: changes in opioid prescribing in the United States. 2006-2015. MMWR Morb Mortal Wkly Rep., 66(26), 697-704. doi: 10.15585/ mmwr.mm6626a4

[11] Jain, Y. (2013). Local Drug Delivery. International Journal of Pharmaceutical Science Invention., 2(1), 33-36.

[12] Joshi, D., Garg, T., Goyal, A. K., \& Rath, G. (2016). Advanced drug delivery approaches against periodontitis. Drug delivery, 23(2), 363-377. http://doi.org/10.3109/10717544.2014.935531

[13] Kholodniak, O. V. (2017). Treatment, prevention and prognosis of localized inflammatory diseases of periodontal tissues (Candidate dissertation).

[14] Kimak, G. B., \& Melnychuk G. M. (2018). Changes in indicators of lipid peroxidation and peroxidation of proteins in the oral fluid of patients with generalized periodontitis of young persons due to complex treatment. Innovations in Dentistry, 1, 17-21.

[15] Matviykiv, T. I., \& Gerelyuk, V. I. (2012). Clinical condition of periodontal tissues in patients with chronic generalized periodontitis on the background of systemic antibiotic concomitant pathology. Halych Medicinal Bulletin, 4(19), 4952.

[16] McCarty, M. F., O'Keefe, J. H., \& DiNicolantonio, J. J. (2016). Pentoxifylline for vascular health: a brief review of the literature. Open Heart, 3(1), e000365. doi: 10.1136/openhrt-2015-000365 
[17] Mira, A., Simon-Soro, A., \& Curtis, M. A. (2017). Role of microbial communities in the pathogenesis of periodontal diseases and caries. Journal of clinical periodontology, 44(18), 23-38. doi: 10.1111/jcpe. 12671

[18] Patalakha, O. V. (2019). Features of the immune response and optimization of treatment of generalized periodontitis in patients with toxic opioid hepatitis (Candidate dissertation).

[19] Schroeder, A. R., Dehghan, M., Newman, T. B., Bentley, J. P., \& Park, K. T. (2019). Association of Opioid Prescriptions from Dental Clinicians for US Adolescents and Young Adults With Subsequent Opioid Use and Abuse. JAMA Intern Med., 179(2), 145-152. doi: 10.1001/jamainternmed.2018.5419

[20] Semenyuk, G. D., Melnychuk, G. M., \& Makarenko, O. A. (2014). Dynamics of oral dysbiosis in patients with generalized periodontitis on the background of complex treatment. Bulletin of Dentistry, 4, 26-30.

[21] Silva, N., Abusleme, L., Bravo, D., Dutzan, N., Garcia-Sesnich, J., Vernal, R., .. \& Gamonal, J. (2015). Host response mechanisms in periodontal diseases. J. Applied Oral Sci., 23(3), 329-355. http://doi.org/10.1590/1678-775720140259

[22] Tokmakova, S. I., \& Lunitsyna, Yu. V. (2014). Features of dental status of patients with opium addiction. Far Eastern Medical Journal, 1, 130-135.

[23] Zubachik, V. M., \& Fedun, I. R. (2017). Biochemical parameters of oral fluid in drug-addicted patients with chronic generalized periodontitis. Clinical Dentistry, 2, 9-14. doi: 10.11603/23119624.2017.2.7741

\section{УЛЬТРАСТРУКТУРНИЙ СТАН ТКАНИН ПАРОДОНТУ ЩУРІВ ПРИ ОПІОЇДНОМУ ВПЛИВІ УПРОДОВЖ ДВОХ ТИЖНІВ ТА ПІСЛЯ ЙОГО ЧОТИРИТИЖНЕВОЇ ВІДМІНИ ЗА УМОВ КОРЕКЦІЇ \\ Фік В.Б., Пальтов Є.В., Кривко Ю.Я.}

Враховуючи, що стоматологічний статус наркозалежних осіб обтяжений численними захворюваннями тканин і органів порожнини рота, у сучасній пародонтології залишаються актуальними питання розробки оптимальної схеми лікувальної тактики з метою відновлення їх трофріки та балансу мікрофрлори ротової порожнини на фооні опіоїдного впливу. Метою роботи було дослідити ультраструктуру тканин пародонту при експериментальній двотижневій дії опіоїду та після його відміни упродовж чотирьох тижнів за умов комплексного медикаментозного коригуючого впливу. Матеріалом дослідження слугували білі щури-самці (22) репродуктивного віку (4,5 - 6 місяців), лінії Wistar, середньою вагою тіла 200 г. Тваринам проводили ін'єкції препарату налбуфін у дозі 0,212 мг/ка впродовж двох тижнів з подальшою його відміною протягом чотирьох тижнів. 3 метою корекції патологічних змін, що виникають при дії опіоїду в тканинах пародонту, застосовано лікарські засоби пентоксифрілін та антибіотик цефртріаксон. Пентоксифілін вводили щоденно внутрішньом'язово протягом чотирьох тижнів після відміни опіоїду (3 - 6 тиждень) у дозі 2,857 мг/ке. Цефртріаксон вводили одноразово, внутрішньом'язово упродовж 11 діб наприкінці експерименту (5 - 6 тижні) в дозі, еквівалентній для щура (2,857 мг/кг). Забір тканин пародонту здійснювали в ділянці ясенного сосочка з подальшим проведенням електронно-мікроскопічного дослідження. Субмікроскопічно встановлено, що структурні компоненти пародонту мають незначні зміни, їх організація наближена до норми. Для ультраструктури всіх ділянок епітеліальної пластинки слизової оболонки ясен характерно пошарове розташування клітин. $B$ епітеліоцитах частина ядер мають інвагінації каріолеми, що свідчить про їх ффункціональну активність. Чіткі контури компактних ядерець і плазмолем. У цитоплазмі більшість органел практично не змінена, у мітохондріях наявні кристи, чітко визначаються тонофріламенти, десмосомальні контакти та базальна мембрана. Контури плазмолем чіткі, міжклітинні контакти збережені, окремі міжклітинні ділянки виглядають потовщеними. Періодонт представлений добре упорядкованими пучками колагенових волокон, клітинні компоненти незмінені. Виявлена субмікроскопічна будова фрібробластів свідчить про їх синтетичну активність, направлену на оновлення міжклітинної речовини сполучної тканини. Електронно-мікроскопічні дослідження гемокапілярів слизової оболонки ясен тварин даної групи показали, що у нешироких їх просвітах наявні фоормені елементи крові, переважно еритроцити. Ядра ендотеліоцитів мали еліпсоподібну форму, невеликі інвагінації каріолеми, чіткі ядерні мембрани, органел було небагато. Периваскулярні простори без ознак набряку. Венули малозмінені, мають широкі просвіти, цитоплазматичні ділянки ендотеліоцитів неширокі, їх ядерні частини випинають у просвіт, базальна мембрана місиями потовщена. Таким чином, субмікроскопічно встановлено, що при відміні опіоїду та застосуванні медикаментозної корекції через 2 тижні опіоїдного впливу, наявні ознаки позитивної динаміки в структурних компонентах пародонту, що пояснюється патогенетичною обгрунтованістю призначення пентоксифіліну при розладах мікроциркуляції, його протизапальною $i$ антиоксидантною дією та у поєднанні з антибактеріальним засобом цефтріаксон забезпечують лікувальну дію на ультраструктурну та фрункціональну організацію тканин пародонту.

Ключові слова: електронно-мікроскопічні дослідження, тканини пародонту, щури, опіоїдний аналгетик, корекція.

\section{УЛЬТРАСТРУКТУРНОЕ СОСТОЯНИЕ ТКАНЕЙ ПАРОДОНТА КРЫС ПРИ ДЕЙСТВИИ ОПИОИДА НА ПРОТЯЖЕНИИ ДВУХ НЕДЕЛЬ И ПОСЛЕ ЕГО ЧЕТЫРЕХНЕДЕЛЬНОЙ ОТМЕНЫ В УСЛОВИЯХ КОРРЕКЦИИ \\ Фик В.Б., Пальтов Е.В., Крывко Ю.Я.}

Учитывая, что стоматологический статус наркозависимых обременен многочисленными заболеваниями тканей и органов полости рта, в современной пародонтологии остаются актуальными вопросы разработки оптимальной схемы лечебной тактики с целью восстановления их трофиики и баланса микрофрлоры ротовой полости на фоне опиоидного воздействия. Целью работы было исследовать ультраструктуру тканей пародонта в эксперименте при двухнедельном воздействии опиоида и после его отмены в течение четырех недель с использованием комплексной медикаментозной коррекции. Материалом исследования послужили белые крысы-самцы (22) репродуктивного возраста (4,5 - 6 месяцев), линии Wistar, средней массой тела 200 г. Проводили животным инъекции препарата налбуфин в течение двух недель, доза составляла 0,212 мг/кг, с последующей его отменой в течение четырех недель. С целью коррекции патологических изменений, возникающих при воздействии опиоида в тканях пародонта, применены лекарственные средства пентоксифиллин и антибиотик цефтриаксон. Пентоксифиллин вводили ежедневно внутримышечно в течение четырех недель после отмены опиоида (3 - 6 неделя) в дозе 2,857 ма/ке. Цефтриаксон вводили однократно в течение 11 суток в конце эксперимента (5 - 6 недель) в дозе, эквивалентной для крысы (2,857 мг/кг). Забор тканей пародонта осуществляли в области десневого 
сосочка с последующим проведением электронно-микроскопического исследования. Субмикроскопически установлено, что структурные компоненты пародонта имеют незначительные изменения, их организация близка к норме. Для ультраструктуры всех участков эпителиальной пластинки слизистой оболочки десны характерно послойное расположение клеток. В эпителиоцитах часть ядер имеют инвагинации кариолемы, что свидетельствует об их фрункциональной активности. Четкие контуры компактных ядрышек и плазмолемм. В цитоплазме большинство органелл практически не изменена, в митохондриях имеются кристы, четко определяются тонофиламенты, десмосомальные контакты и базальная мембрана. Контуры плазмолемм отчетливые, межклеточные контакты сохранены, отдельные межклеточные участки выглядят утолщенными. Периодонт представлен хорошо структурированными пучками коллагеновых волокон, клеточные компоненты изменены. Субмикроскопическое строение фибробластов свидетельствует об их синтетической активности, направленной на обновление межклеточного вещества соединительной ткани. Электронно-микроскопические исследования гемокапилляров слизистой оболочки десны животных данной группы показали, что в нешироких их просветах имеются форменные элементы крови, преимущественно эритроциты. Ядра эндотелиоцитов имеют эллипсообразную фрорму, небольшие инвагинации кариолемы, четкие ядерные мембраны, немного органелл. Периваскулярные пространства без признаков отека. Венулы малоизмененные, имеют широкие просветы, иитоплазматические участки эндотелиоцитов неширокие, их ядерные части выпячивают в просвет, базальная мембрана местами утолщена. Таким образом, субмикроскопически установлено, что при отмене опиоидного анальгетика и применении медикаментозной коррекции через 2 недели опиоидного воздействия, имеется положительная динамика в структурных компонентах пародонта, что объясняется патогенетической обоснованностью назначения пентоксифиллина при расстройствах микроциркуляции, его противовоспалительным и антиоксидантным эфрфектом и в сочетании с антибактериальным средством цефртриаксон обеспечивают лечебное воздействие на ультраструктурную и функциональную организацию тканей пародонта.

Ключевые слова: электронно-микроскопические исследования, ткани пародонта, крысы, опиоидный анальгетик, коррекция. 